\title{
Knowledge Towards Immunizations among Traditional Birth Attendants in Wassit Governorate
}

\author{
Assistant lecturer Sameeha Naser Abed \\ Master Community Health Tech. in. institute technical of kut
}

\begin{abstract}
:
Objective: This study aimed to assess the knowledge of traditional birth attendants regarding

Immunization.
\end{abstract}

Methodology: This study was a cross sectional study conducted at wassit government, for a period of 4 months extending from $1^{\text {st }}$ of March 2015 to the $1^{\text {St }}$ June 2015 . The study sample included 64 traditional birth attendants whose ages were 21 years and above. Data collection was obtained by direct interview ( using the questionnaire form). The Research objectives are explained to TBAs and an emphasis on the confidentiality of information. Results: forty-sixty (64) TBAs were included in this study, Significantly over $75 \%$ (48) found in age $>40$ years. $21(32.81 \%)$ had read and write level . They were predominantly married, $67.19 \%$. In addition, They were residing in an urban area. Relative to length of experience, the highest frequency of TBAs were in the length of experience of TBAs $(>10$ ) years was $53.13 \%$. nearly half of them $(57.81 \%)$ were trained in the sectors of health. High knowledge towards Immunizations was observed among (93.75\%) of TBAs Recommendations: Depending on the high rate of TBAs' knowledge concerning Immunization recommend to train TBAs and utilize of them in the provision of advice on Immunization, especially in rural areas. Consolidation of relations between TBAs and health sectors, because of the significant impact on the high level of disease prevention, through seminars, lectures and open meetings.

Key words : Traditional birth attendants; knowledge , Immunizations.

\section{Introduction}

Immunization is fundamental for an effective, safest \& efficient preventive management of major illnesses [1,2]. Remarkable, it's considered the most important pillars of the primary health care and the pest indicators that can be relied upon to evaluate the outcome of the health services provided to various social and economic classes $^{[3]}$ Besides the provision of basic vaccines which contributes to the reduction maternal and 
childhood morbidity \& mortality ${ }^{[4,2]}$. TBAs seem to play an significant role in encouraging immunization, especially in the areas where the births predominatingly in homes ${ }^{[5]}$ This is because TBAs have a special social status, and enjoys the trust and esteem and acceptance from women and their belief that TBAs provide the preferable services as compared with the health workers ${ }^{[6]}$ furthermore, one of the objective of the TBAs' training programs was to aimed to strengthen the linkages between health system and community which will be reflected positively on maternal and child protection ${ }^{[7]}$. In this study, the knowledge about immunization were assessed among TBAs.

Subjects and Methods: Administrative Arrangement: A formal approval was obtained from the Wasit Health Directorate to conduct this study. A verbal consent has been taken from each TBAs before her participation. the purpose of the study was clearly explained to the patients - All the information was kept confidential.

Place, time \& design of Study : This was a cross sectional study conducted at seventeen sub districts in wassit government, north of Baghdad, Iraq's capital, for a period of 4 months extending from $1^{\text {st }}$ of March 2015 to the $1^{\text {St }}$ June 2015

Study sample: The study sample included 64 traditional birth attendants (37 trained and 27 untrained) whose ages were 21 years and above

The Data Collection: The method of collecting information depends on direct interview (face to face or by phone), with TBAs. Data collection was obtained by direct interview ( using the questionnaire form) with TBAs included information concerning demographic variables such as age, residence, marital status , educational, Employment status. The knowledge information ( Is a set of 7 questions regarding the traditional birth attendants knowledge). The knowledge score were classified as good and acceptable and poor depending upon the score. The answer is correct was scored two, and the answer is incorrect was scored one, the general awareness scores ranged from 7 to 14 (Minimum=7, Maximum=14, Medium=10.5). The medium was calculated for each question and those score below the medium consider poor score, above or equal 10.5 acceptable \&good score.

The Research objectives are explained and an emphasis on the confidentiality of 
information.

Statistical analysis: The information regarding each case was transferred into code sheets and data entry was and statistical analysis was done using the Minitab (version16) and Excel application
2007, the data description were presented as frequencies and percentages. Limitation of the Study: This study is limited by inability to cover all TBAs in wassit governorate

\section{Results:}

Socio-demographics characteristics: The demographic characteristics of the sample are summarized in Table 1. forty-sixty (64) TBAs were included in this study, three-quarters of TBAs (48) found in age $>40$ years. 21 (32.81\%) had read and write level, while 15 $(23.44 \%)$ of the participants had Intermediate education, and only $3.11 \%$ had institute \&higher education .

They were predominantly married, $67.19 \%$, while $21.88 \%$ were widowed. nearly half of them (54.69\%) were unemployed In addition, They were residing in an urban area. Relative to Length of Experience, the highest frequency of TBAs were in the length of experience of TBAs $(>10)$ was $53.13 \%$. Out of $57.81 \%$ who were trained in the sector of health.

Table-1: Socio-demographic characteristics of the study population

\begin{tabular}{|c|c|c|}
\hline \multirow[t]{2}{*}{ Variable } & \multicolumn{2}{|c|}{ TBAs } \\
\hline & No. & $\%$ \\
\hline \multicolumn{3}{|l|}{ Age } \\
\hline r) -40 & 16 & 25.00 \\
\hline$\geq 40$ & 48 & 75.00 \\
\hline \multicolumn{3}{|l|}{ Education level } \\
\hline Illiterate & 4 & 6.35 \\
\hline Read and write & 21 & 32.81 \\
\hline Primary & 11 & 17.19 \\
\hline Intermediate & 15 & 23.44 \\
\hline Secondary & 11 & 17.19 \\
\hline Institute \&Higher & 2 & 3.11 \\
\hline \multicolumn{3}{|l|}{ Employment status } \\
\hline Employed & 29 & 45.31 \\
\hline unemployed & 35 & 54.69 \\
\hline \multicolumn{3}{|l|}{ Marital status } \\
\hline single & 1 & 1.56 \\
\hline Married & 43 & 67.19 \\
\hline Divorced & 6 & 9.38 \\
\hline Widowed & 14 & 21.88 \\
\hline
\end{tabular}


Thi-Qar Medical Journal (TQMJ): Vol.(14), No.(2), 2017

\begin{tabular}{|c|c|c|}
\hline Place of residence & \multicolumn{2}{|c|}{} \\
\hline Urban & 53 & $\mathbf{8 2 . 8 1}$ \\
\hline Rural & 11 & $\mathbf{1 7 . 1 9}$ \\
\hline Length of Experience & 9 & $\mathbf{1 4 . 0 6}$ \\
\hline$<0$ & 21 & $\mathbf{3 2 . 8 1}$ \\
\hline-10 & 34 & $\mathbf{5 3 . 1 3}$ \\
\hline$>10$ & 37 & $\mathbf{5 7 . 8 1}$ \\
\hline TBAs & 37 & $\mathbf{4 2 . 1 9}$ \\
\hline Trained & 27 & $\mathbf{1 1}$ \\
\hline Untrained & Wastrated in Table \\
\hline
\end{tabular}

TBAs' knowledge about Immunization was assessed and the results are illustrated in Table

2. study results revealed that was $98.44 \%$ of the TBAs had heard about immunization. Majority of TBAs, $98.44 \%$ TBAs thought that immunization were protect from diseases. The most vaccines known by TBAs are the polio and Hepatitis B, which represented for $75.56 \%$ and $62.22 \%$ respectively. followed by the Measles and BCG, $55.56 \%$ for both. The Tetanus is the fourth vaccine known by TBAs (46.67\%). The result shows that about $37.78 \%$ and $31.11 \%$ of TBAs know the Whooping cough and Diphtheria. Majority among the TBAs, $95.31 \%$ believed that immunization were begin at birth. Significantly, over $85 \%$ of TBAs believed that vaccines don't have harmful effect. All of TBAs except two (96.88\%), have knowledge about vaccines pregnancy. Similarly, $18.75 \%$ of TBAs believed that Tetanus vaccine during pregnancy can prevents Neonatal tetanus.

Table2: Knowledge of the study sample regarding immunization

\begin{tabular}{|c|c|c|c|}
\hline Questions & Answers of TBAs & No. & $\%$ \\
\hline \multirow[t]{2}{*}{ Aware to immunization? } & Yes & 63 & 98.44 \\
\hline & No & 1 & 1.56 \\
\hline \multirow[t]{2}{*}{ Do vaccine protects diseases? } & Yes & 63 & 98.44 \\
\hline & No & 1 & 1.56 \\
\hline \multirow{2}{*}{$\begin{array}{l}\text { Number of disease can prevent known by } \\
\text { immunization? }\end{array}$} & Less than 3 & 32 & 50.00 \\
\hline & more than 3 & 32 & 50.00 \\
\hline \multirow[t]{7}{*}{ What are the diseases that vaccines can prevent? } & Polio & 34 & 75.56 \\
\hline & Diphtheria & 14 & 31.11 \\
\hline & Measles & 25 & 55.56 \\
\hline & Tetanus & 21 & 46.67 \\
\hline & Whooping cough & 17 & 37.78 \\
\hline & Tuberculosis & 25 & 55.56 \\
\hline & Hepatitis B & 28 & 62.22 \\
\hline At any age begin vaccinations? & At birth & 61 & 95.31 \\
\hline
\end{tabular}




\begin{tabular}{|c|c|c|c|}
\hline & $\begin{array}{c}\text { During the first } 6 \\
\text { weeks }\end{array}$ & 2 & 3.13 \\
\hline & At any age & 1 & 1.56 \\
\hline \multirow[t]{2}{*}{ Are vaccines harmful effect? } & Yes & 8 & 12.50 \\
\hline & No & 56 & 87.50 \\
\hline \multirow[t]{2}{*}{ Do you have knowledge about vaccines pregnancy? } & Yes & 62 & 96.88 \\
\hline & No & 2 & 3.13 \\
\hline \multirow[t]{3}{*}{ Tetanus vaccine during pregnancy can prevents? } & Neonatal tetanus & 12 & 18.75 \\
\hline & $\begin{array}{l}\text { Mother from } \\
\text { tetanus }\end{array}$ & 46 & 71.88 \\
\hline & Don't know & 6 & 9.38 \\
\hline
\end{tabular}

Distribution of knowledge about immunization across all respondents in wassit is highlighted in Table 3. Worth mentioning that the knowledge of TBAs in this study with respect to immunization is highly $(93.75 \%)$.

Table 3: Knowledge' scores of TBAs .

\begin{tabular}{|c|c|c|}
\hline Knowledge score & \multicolumn{2}{|c|}{ TBAS } \\
\hline & No & $\%$ \\
\hline Poor & 4 & 6.25 \\
\hline Good and acceptable & 60 & 93.75 \\
\hline Total & 64 & 100 \\
\hline
\end{tabular}

\section{Discussion:}

The age distribution in this study revealed that $(75.00 \%)$ of the respondents of TBAs were $\geq 40$ years of age. This was comparable to a Pakistani study Khalid Ismail et al, 2007 in which it was reported that $85 \%$ of TBAs were $\geq 40$ years of age ${ }^{[8]}$. More than one-third of the studied sample were read and write. This differs from study conducted by
Gloria Hamela, et al, 2014 in Malawi, who found that fifty percent of TBAs were illitrate ${ }^{[9]}$. This study detected that more than $65 \%$ of TBAs included in the study were married. This is in agreement with results of study done by Dismas B Vyagusa et al, 2013 in Tanzania ${ }^{[10]}$.

The study shows that nearly $60 \%$ of TBAs were trained, the result goes with the findings obtained by Khalid 
Ismail et al, 2007 in Pakstan, who found that $52 \%$ of TBAs were trained ${ }^{[8]}$. The present study revealed that there was $53.13 \%$ of the studied sample to have more than 15 experience as TBAs. Similar findings were reported by Tina Y. Falle1 et al , 2009 in Nepal, he found that $44.1 \%$ of TBAs were have more than 15 experience $^{[5]}$. It is worth mentioning that the knowledge of TBAs in this study with respect to immunization is highly $(93.75 \%)$.

\section{Conclusions:}

Depending on the results of the study conclude that Three quarters of TBAs in this study were forty years and over of age. Majority of TBAs were read and write and most of them from urban areas and more than half of the studied sample have more than 15 experience as TBAs and them were trained by the health sector. The study also concluded that TBAs' knowledge regarding Immunization was extremely high.

\section{Recommendations:}

The main recommendations of the present study are consolidation of relations between TBAs and health sectors, because of the significant impact on the high level of disease prevention. Through seminars, lectures and open meetings. Depending on the high rate of TBAs' knowledge concerning Immunization recommend to train TBAs and utilize of them in the provision of advice on Immunization.

\section{References:}

1. Shamila Hamid, Immunization of Children in a Rural Area of North Kashmir, India: A KAP Study, India. Journal of Health and Allied Sciences, 1 (2012), Vol 11, ISSN:- 0972-5997.

2. Vineeta Rathaur, Anupma Mehrotra and Tejpal Rathore, knowledge , attitude \& practice toward Immunization among working \& non working mothers in Bareilly city, Indian Streams Research Journal, 12 (2014), Vol 3 , ISSN:-2230-7850,

3. Bhola Nath, Singh JV, Shally Awasthi, Vidya Bhushan, Vishwajeet Kumar, Singh SK , KAP Study on Immunization of Children in a City of North India - A 30 Cluster Survey. Online Journal Health Allied Sciences, 1 (2008), Vol 7, ISSN 09725997. 
4. Chaitra K. M, Yashoda H. T, Knowledge of vaccination among nursing students. Journal of Evolution of Medical and Dental Sciences, 20 (2014) Vol. 3, P.P: 5637-5641, ISSN2278-4802.

5. Tina Y. Falle, Luke C. Mullany, Nandita Thatte, Subarna K. Khatry, Steven C. LeClerq, Gary L. Darmstadt, Joanne Katz, and James M. Tielsch, Potential Role of Traditional Birth Attendants in Neonatal Healthcare in Rural Southern Nepal Journal health poplu nutr, 27(2009), Vol.1, P.P;53-61, ISSN 1606-0997.

6. Noma Owens Ibie, Traditional Birth Attendants and the Pursuit of Maternal and Child Health in Nigeria (2011).

7. Seroney, G.C.,Minnie, K., OtienoAyayo, Z.N., Mulaudzi, F.M., and Nyangena, E., Knowledge, Attitude and Practices of trained traditional birth attendantson HIV/AIDS, Kenya. Baraton Interdisplinary Research Journal, 2 (2012), Vol.1, P.P; 8 - 16. 8. Khalid Ismail, Rubina Sarmad, M. Akram $\mathrm{CH}$, Assessment of knowledge about prophylaxis of neonatal tetanus among traditional birth attendents . Biomedical, (2007), Vol. 23 .

9. Gloria Hamela, Charity Kabondo, Tapiwa Tembo, Chifundo Zimba, Esmie Kamanga, Innocent Mofolo, Bertha Bulla, Christopher Sellers, R.C. Nakanga, Clara Lee, Francis Martinson, Irving Hoffman, Charles van der Horst and Mina C. Hosseinipour, Evaluating the benefits of incorporating traditional birth attendants in HIV Prevention of Mother to Child Transmission service delivery in Lilongwe. Malawi African Journal of Reproductive Health March, 18 (2014), Vol.1, P.P; 27-34. 10. Dismas B Vyagusa, Godfrey M Mubyazi and Melchiory Masatu, Involving traditional birth attendants inemergency obstetric care in Tanzania: policy implications of a study of their knowledge and practices in Kigoma Rural District. International Journal for Equity in Health, (2013),P.P; 12:83. 


\title{
تقييم المعارف إزاء التحصين بين القابلات التقليديات في محافظة واسط
}

\author{
مدرس مساعد سميحة ناصر عبد سعيد \\ ماجستير تقتيات صحة مجتمع \لمعهد الكوت التقني.
}

الهذف : هدفت هذه الدر اسة إلى تقييم معارف القابلات التقليديات حول التحصين . منهجية البحث : أجريت دراسة مقطعية في محافظة واسط، لمدة 4 أثهر امندت من الأول من آذار 2015 إلى الأول من حزيران عام 2015. وشملت عينة الدراسة 64 من القابلات التقليديات التي تراوحت أعمار هن من 21 سنة فما فوق .تم جمع البيانات عن طريق المقابلة المبانشرة (باستخدام استمارة استبيان). حيث تم شرح أهداف البحث إلى القابلات مع التأكيد على سرية المعلومات. النتائج : شملت الدراسة أربع وستون قابلة، بيت الدراسة أن أكثر من 75٪ (48) تجاوزن 40 سنة من العمر ـ كما أن 21 (\% 32.81) تقر أو تكتب و اغلبهن متزوجات 67.19٪ . بالإضافة إلى ذلك، يقيمن في

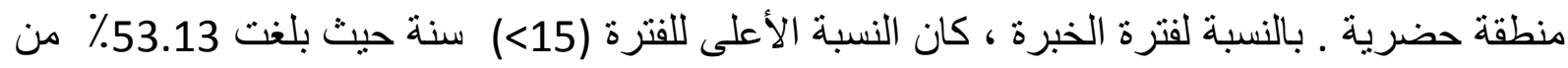

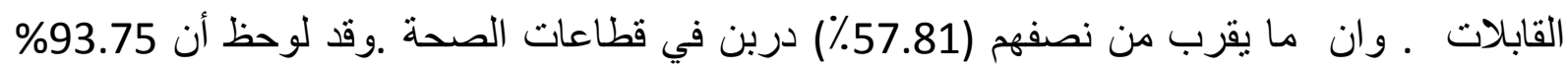

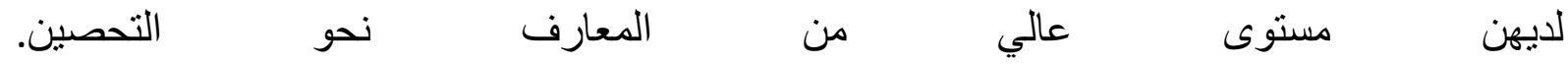


التوصيات : بناء على المستوى العالي من المعرفة المتعلقة التحصين للقابلات "توصي الدراسة بتدريب القابلات و الاستفادة منهن في تقديم المشورة بشأن التحصين، وخاصة في المناطق الريفية .مع نوطيد العلاقات بين القابلات و القطاعات الصحية، مما له من تأثير كبير على مستوى الوقاية من الأمر اض من خلال الندو ات و المحاضر ات و اللقاءات المفتوحة. الكلمات الافتتاحية : القابلات التقليديات , المعرفة , التحصين. 